NBER WORKING PAPER SERIES

\title{
EMPLOYMENT, INNOVATION, AND PRODUCTIVITY: EVIDENCE FROM ITALIAN MICRODATA
}

\author{
Bronwyn H. Hall \\ Francesca Lotti \\ Jacques Mairesse \\ Working Paper 13296 \\ http://www.nber.org/papers/w13296 \\ NATIONAL BUREAU OF ECONOMIC RESEARCH \\ 1050 Massachusetts Avenue \\ Cambridge, MA 02138 \\ August 2007
}

We would like to thank the Mediocredito-Capitalia research department for having kindly supplied firm level data for this project. We thank also an anonymous referee who provided insightful comments, Bettina Peters, Massimo Sbracia, Roberto Torrini, Marco Vivarelli, and participants at the Schumpeter Society Meetings (Nice, June 2006), the Bank of Italy (Rome, November 2006), Sant'anna School of Advanced Studies (Pisa, February 2007), and at the Vth International Industrial Organization Conference (Savannah, April 2007) for useful comments. B. H. Hall gratefully acknowledges financial support from the Ente Luigi Einaudi. The views expressed herein are those of the author(s) and do not necessarily reflect the views of the National Bureau of Economic Research or those of the Bank of Italy.

(C) 2007 by Bronwyn H. Hall, Francesca Lotti, and Jacques Mairesse. All rights reserved. Short sections of text, not to exceed two paragraphs, may be quoted without explicit permission provided that full credit, including $\odot$ notice, is given to the source. 
Employment, Innovation, and Productivity: Evidence from Italian Microdata

Bronwyn H. Hall, Francesca Lotti, and Jacques Mairesse

NBER Working Paper No. 13296

August 2007

JEL No. D24,J0,J20,L20,O30

\begin{abstract}
$\underline{\text { ABSTRACT }}$
Italian manufacturing firms have been losing ground with respect to many of their European competitors. This paper presents some empirical evidence on the effects of innovation on employment growth and therefore on firms' productivity with the goal of understanding the roots of such poor performance. We use firm level data from the last three surveys on Italian manufacturing firms conducted by Mediocredito-Capitalia, which cover the period 1995-2003. Using a slightly modified version of the model proposed by Harrison, Jaumandreu, Mairesse and Peters (HJMP 2005), which separates employment growth rates into those associated with old and new products, we find no evidence of significant employment displacement effects stemming from process innovation. The sources of employment growth during the period are split equally between the net contribution of product innovation and the net contribution from sales growth of old products. However, the contribution of product innovation to employment growth is somewhat lower than in the four European countries considered in HJMP 2005, and the contribution of innovation in general to productivity growth is almost nil in Italy during this period.

Bronwyn H. Hall

Department of Economics

549 Evans Hall

UC Berkeley

Berkeley, CA 94720-3880

and NBER

bhhall@nber.org

Francesca Lotti

Economic Research Department

Bank of Italy

via Nazionale 91

00184 Rome

ITALY

francesca.lotti@bancaditalia.it

Jacques Mairesse

INSEE, CREST

15, Boulevard Gabriel PERI

92245 MALAKOFF CEDEX

FRANCE

and NBER

mairesse@ensae.fr
\end{abstract}




\section{Introduction}

Italian manufacturing firms have been losing ground with respect to many of their European competitors. This weak performance is not entirely attributable to the preponderance of traditional sectors in Italy, which are more exposed to competition from emerging countries than the advanced sectors: not only do the traditional sectors account for larger shares of employment than in other countries, but they also display a significant positive productivity growth differential (see Lotti and Schivardi, 2005 and IMF, 2006). Also, many indicators of innovation activity, both in terms of input and output, signal that the Italian economy is lagging behind. Can this lower innovative activity account for slower productivity growth in Italian manufacturing?

This paper presents some empirical evidence on the effects of innovation on employment growth, and therefore on firms' productivity, with the goal of contributing to our understanding the roots of such poor performance. We use a simple framework pioneered by Harrison, Jaumandreu, Mairesse and Peters (2005, henceforth HJMP 2005) to disentangle the effects of innovation on employment and productivity growth applied to a panel of nearly 9,500 Italian firms observed over a nine year period (1995-2003). These data come from the last three surveys of Italian manufacturing firms conducted by Mediocredito-Capitalia (hereafter MCC), covering the period 1995-2003. These surveys contain balance sheets items and, more importantly, qualitative information on firm characteristics, with a focus on innovation activities.

Using instrumental variable regressions to correct for the endogeneity of our innovation measures, we provide evidence that there is no significant employment displacement effects stemming from process innovation, and therefore no productivity growth associated with such innovation for our firms during the study period. We also show that product innovation contributes about half the employment growth, while sales expansion of old products accounts for the other half, in spite of some efficiency gain in their production. Correspondingly, we find almost no contribution to productivity growth from product innovation per se, leaving all productivity growth to be accounted for by the industry specific trends in productivity.

In the next section of the paper we discuss prior empirical evidence on innovation and employment growth. We then present the model we use for estimation, 
and discuss measurement issues raised by the data that are available to us. This is followed by a presentation of the data and the results of estimating the model on our samples of firms. In the final sections of the paper we compare our results to those of HJMP 2005 for France, Germany, Spain, and the U.K. and draw some conclusions.

\section{Theoretical and empirical underpinnings}

The debate about the impact of technological change on employment is an old one (Jean-Baptiste Say, 1803; 1964 edition); since that time, scholars have been trying to disentangle the displacement and compensation effects of innovation both from a theoretical and an empirical point of view, often pointing out the different implications of process and product innovation. In theory, other things equal, the introduction of new or significantly improved products increases demand for innovating firms, and therefore also their employment levels. However, innovating firms, enjoying temporary market power, may set profit-maximizing prices and reduce output enough so that the net effect on employment after substitution to the new good can be negative. On the other hand, even though process innovation is typically labor-saving, its effect on employment is not straightforward. If the same output can be made with fewer workers, the firm can share this efficiency gain with the consumers via lower prices, thereby increasing demand. Depending on market structure, the demand elasticity, and the elasticity of substitution between capital and labor, compensation mechanisms can counterbalance the labor saving effect of process innovation (for a detailed survey on these compensation mechanisms, see Spiezia and Vivarelli, 2002).

Empirically, the identification of displacement and compensation effects is particularly difficult, because firms are often involved in product and process innovation together. Nevertheless, the empirical literature on the effects of innovation on employment has made significant progress since the 1990s, when micro-economic data on individual firms began to be widely available and econometric techniques applicable to such data have been developed to take care of selectivity and endogeneity problems. ${ }^{1}$

While there is a widespread consensus in this literature on the positive impact

\footnotetext{
${ }^{1}$ See for surveys Van Reenen (1997), Hall and Kramarz (1998), Vivarelli and Pianta (2000), Chennels and Van Reenen (2002), Lachenmaier and Rottmann (2006).
} 
of product innovation on employment at the firm-level, the evidence about process innovation is less clear-cut. Using cross-sectional data for Germany, Zimmermann (1991) finds that technological progress was responsible for the fall of employment during the 1980s, while Entorf and Pohlmeier (1990) find no significant effects. Based on a series of surveys, Brouwer et al. (1993) find a positive effect for product innovation on employment growth for the Netherlands in the 1980s, but a negative one for overall innovation (as measured by total $R \& D$ expenditures). Using the Community Innovation Survey (CIS) data for Germany, Peters (2004) finds a significantly positive impact of product innovation on employment, and a negative one for process innovation. In contrast, Blechinger et al. (1998) support the evidence of a positive relationship between both product and process innovation and employment growth in the Netherlands and in Germany. Blanchflower and Burgess (1998) and Doms et al. (1995) find positive impacts of process innovation on employment growth, respectively in Australia and the U.K., and in the U.S., whereas the study by Klette and Forre (1998) does not show any clear relation between innovation and employment in Norway. Greenan and Guellec (2000), combining firm-level panel data with innovation surveys, observe that innovating firms (and industries) have created more jobs than non-innovating ones. Piva and Vivarelli (2005), build a balanced panel of 575 Italian Manufacturing firms based on different surveys by Mediocredito-Capitalia for the period 1992-1997, and estimate a small but significantly positive relation between innovative investment and employment. They do not rely, however, on the usual classification of innovation in product and process, but instead consider a measure of investment in new innovative equipment, proxying for embodied technological change and thus close to an indicator of process innovation. Finally, the paper by HJMP 2005, which we follow here, uses CIS3 data (1998-2000) for France, Germany, U.K., and Spain. The authors find that although process innovation displaces employment, compensation effects from product innovation dominate in the four countries, albeit with some differences between them. ${ }^{2}$

Summarizing the results of this large set of firm-level studies, most of them have found positive effects of product innovation on employment, but mixed evidence

\footnotetext{
${ }^{2} \mathrm{~A}$ comparison of our results with those in HJMP 2005 is presented in Section 5.
} 
for process innovation. The net impacts of process innovation seem positive in the U.S. and Australia, but small and negative in European countries. Summing up, the overall effects of innovation on employment appear to be generally positive at the firm level in developed economies.

\section{A model of innovation and employment}

\subsection{Theoretical framework}

The framework presented here is a variation of the one described in the paper by HJMP 2005, which is specifically tailored for the type of innovation data available to us. In this framework, a firm produces two kinds of products in period $t$ : old or only marginally modified products ("old products", denoted $Y_{1 t}$ ) and new or significantly improved products ("new products", $Y_{2 t}$ ). Firms are observed for two periods, $t=1$ and $t=2$ and innovation occurs between the two periods (if it occurs at all). Therefore by definition, in the first period, only old products $\left(Y_{11}\right)$ are available, so that $Y_{21}=0$.

We assume that the production functions for old and new products are separable with both having constant returns to scale in capital, labor and intermediate inputs. We also assume that they are identical except for a Hicks neutral efficiency parameter, which can depend on firms' investments in process innovation. New products can be made with higher or lower efficiency with respect to old products.

We can thus write the firm's production function for a product of type $i$ in period $t$ as:

$$
Y_{i t}=\theta_{i t} F\left(K_{i t}, L_{i t}, M_{i t}\right), \quad i=1,2 ; t=1,2
$$

where $\theta$ represents efficiency, $K, L$ and $M$ stand for capital, labor and materials, respectively. ${ }^{3}$ Or, assuming cost minimization, we can write the firm's cost function as the following:

\footnotetext{
${ }^{3}$ Actually, we do not have capital and materials in our data, and have to omit these two factors in our implementation of the model. This amounts to using labor productivity instead of total factor productivity (TFP), and assuming that within industry firm annual growth in capital and materials use is equal to that in labor (i.e., equal once we control for industry and year).
} 


$$
C\left(w_{1 t}, w_{2 t}, Y_{1 t}, Y_{2 t}, \theta_{1 t}, \theta_{2 t}\right)=c\left(w_{1 t}\right) \frac{Y_{1 t}}{\theta_{1 t}}+c\left(w_{2 t}\right) \frac{Y_{2 t}}{\theta_{2 t}}+F
$$

where the marginal cost $c(w)$ is a function of the factors price vector $w$, and $F$ represents fixed costs. According to Shephard's Lemma, we also have:

$$
L_{i t}=c_{L}\left(w_{i t}\right) \frac{Y_{i t}}{\theta_{i t}}
$$

where $c_{L}\left(w_{i t}\right)$ represents the derivative of the marginal cost with respect to the wage.

The employment growth from period $t=1$ to period $t=2$ can be decomposed in two terms: $\frac{L_{12}-L_{11}}{L_{11}}$, the contribution to growth from the old products and $\frac{L_{22}-L_{21}}{L_{11}}=\frac{L_{22}}{L_{11}}$, the contribution from the new products. ${ }^{4}$ We can therefore write it as follows:

$$
\frac{\Delta L}{L}=\frac{L_{12}-L_{11}}{L_{11}}+\frac{L_{22}}{L_{11}}
$$

or, using equation (3),

$$
\frac{\Delta L}{L}=\left(\frac{c_{L}\left(w_{12}\right) Y_{12} / \theta_{12}-c_{L}\left(w_{11}\right) Y_{11} / \theta_{11}}{c_{L}\left(w_{11}\right) Y_{11} / \theta_{11}}\right)+\frac{c_{L}\left(w_{22}\right) Y_{22} / \theta_{22}}{c_{L}\left(w_{11}\right) Y_{11} / \theta_{11}}
$$

Assuming that the derivative of the marginal cost with respect to wage does not change over time, and is equal for old and new products, that is $c_{L}\left(w_{11}\right)=c_{L}\left(w_{12}\right)=c_{L}\left(w_{21}\right)=c_{L}\left(w_{22}\right)$, we can show that the following holds approximately:

\footnotetext{
${ }^{4}$ When both old and new products exist in both periods the overall growth rate of employment can be expressed as the share-weighted sum of growth rates in the two products. The present decomposition (4) is an extension of this formula, when the new products only exist in the second period and old products are produced (more or less efficiently) in the two periods.
} 


$$
\frac{\Delta L}{L} \cong-\left(\frac{\theta_{12}-\theta_{11}}{\theta_{11}}\right)+\left(\frac{Y_{12}-Y_{11}}{Y_{11}}\right)+\frac{\theta_{11}}{\theta_{22}} \frac{Y_{22}}{Y_{11}}
$$

According to equation (5), employment growth is determined by three terms. The first is the rate of change in efficiency in the production of old products: it is expected to be larger for those firms that introduce process innovations related to old product production. The second term is the growth of old product production, and the third is the labor increase from expansion in production due to the introduction of new products or the effect of product innovation on employment growth. This effect depends on the relative efficiency $\theta_{11} / \theta_{22}$ of the production processes of old and new products. If new products are made more efficiently than old ones, this ratio is less than unity, and employment does not grow at the same pace as the output growth accounted for by new products.

\subsection{Estimation strategy}

Equation (5) implies the following estimation equation:

$$
l=\alpha_{0}+y_{1}+\beta y_{2}+u
$$

where $l$ is the growth rate of employment between $t=1$ and $t=2, y_{1}$ is the contribution of old products to output growth $\left(\frac{Y_{12}-Y_{11}}{Y_{11}}\right), y_{2}$ is the contribution of new products to output growth $\left(\frac{Y_{22}}{Y_{11}}\right)$, and $u$ is a random disturbance expected to have zero mean conditional to a suitable set of instruments. In this specification, the parameter $\alpha_{0}$ represents the negative of the average efficiency growth in the production of the old product (i.e., labor productivity growth), while the parameter $\beta$ measures the marginal cost in efficiency units of producing new products relative to that for old products. If $\beta$ is equal to unity, efficiency in the production of old and new products is the same; if $\beta<1$, new products are produced more efficiently.

Process innovation can change the efficiency of producing both old and new products and equation (6) can be easily modified to take this into account as follows: 


$$
l=\left(\alpha_{0}+\alpha_{1} d_{1}\right)+y_{1}+\left(\beta_{0}+\beta_{1} d_{2}\right) y_{2}+u
$$

where $d_{1}$ and $d_{2}$ are dummy variables which take value one if the firm introduced process innovation related to the production of old and new products respectively. Because it is impossible to know from the survey what share of its process innovation the firm devotes to new versus old products, in the empirical exercise we experiment with different alternatives of equation (7) (see Table 4), and we end up choosing as our preferred equation the following alternative:

$$
l=\alpha_{0}+\alpha_{1} d_{3}+y_{1}+\beta y_{2}+u
$$

where $d_{3}$ is a dummy variable for process innovation only (i.e., $d_{3}=\left(d_{1}\right)\left(1-d_{2}\right)$.

Despite its simplicity, equation (8) captures two effects of innovation. First, the variable $y_{2}$ allows us to identify the gross effect of product innovation on employment. Second, the dummy for process innovation only allows us to identify directly the productivity (or displacement) effect of process innovation on employment. It is worth noting also that the variable $y_{1}$ is affected by three different forces: (1) "autonomous" variation in the demand of old products, due to exogenous market conditions; (2) a "compensation" effect induced by a price changes in old products following process innovation; and (3) a "substitution" effect stemming from the introduction of new products. The latter two effects are expected to be respectively positive and negative respectively for growth in old product sales. Unfortunately, without additional data on the demand side, it is impossible to disentangle these three effects.

By simply by rearranging terms, we can rewrite equation (8) as a labor productivity equation:

$$
y-l=y_{1}+y_{2}-l=-\alpha_{0}-\alpha_{1} d_{1}-(1-\beta) y_{2}-u
$$

which is helpful in interpreting the magnitude and the sign of the estimated coefficients (the dependent variable is the growth of real output per worker). We will use equation (8) later in the paper to provide a decomposition of the sources of employment growth, and equation (9) to show the corresponding decomposition in 
terms of productivity growth.

\subsection{Measurement issues}

In order to estimate equation (6) (and equations 7 to 9 as well), we must approximate real production $\left(Y_{1}\right.$ and $\left.Y_{2}\right)$ with nominal sales, and this creates a measurement problem, since we do not observe production price changes at the firm level, and since both firm output and prices are affected by movements in demand. It is also the case that old and new products' prices do not necessarily have the same patterns of change and that they will probably remain unknown to us, even if firm price changes for total output were available. Furthermore, it is likely that price changes for new goods will not be adjusted for quality changes as they should be in principle for an appropriate measure of firm real output growth. In this sub-section of the paper we show that using nominal sales growth instead of real output growth in our equation implies that the coefficient of growth due to new products combines two effects: the relative efficiency of producing the new and old products and their relative price, which reflects in part their relative quality differences.

By definition, the nominal and real growth rates of sales of old products $g_{1}$ and $y_{1}$ and the corresponding growth rate of prices $\pi_{1}$ are related as follows:

$$
g_{1}=\frac{P_{12} Y_{12}-P_{11} Y_{11}}{P_{11} Y_{11}} \quad \pi_{1}=\frac{P_{12}-P_{11}}{P_{11}} \quad \text { implying } \quad\left(1+y_{1}\right)=\frac{\left(1+g_{1}\right)}{\left(1+\pi_{1}\right)}
$$

For $\pi_{1}$ and/or $y_{1}$ not too large we can approximate $y_{1}$ as $\left(g_{1}-\pi_{1}\right)$.

In accordance with the definition of the "growth rates" of sales in new products (see footnote 4 above), we define the "growth rate" in their prices $\pi_{2}$ as the difference in the prices of the new products with respect to the old products, that is:

$$
g_{2}=\frac{P_{22} Y_{22}}{P_{11} Y_{11}} \quad \pi_{2}=\frac{P_{22}-P_{11}}{P_{11}} \quad \text { implying } \quad y_{2}=\frac{g_{2}}{\left(1+\pi_{2}\right)}
$$

Substituting $g_{1}$ and $g_{2}$ for $y_{1}$ and $y_{2}$, which are not observable, equation (6) thus becomes the following: 


$$
l-\left(g_{1}-\pi_{1}\right)=\alpha_{0}+\beta \frac{g_{2}}{1+\pi_{2}}+u
$$

Unfortunately equation (12) is still not suitable for estimation, because neither $\pi_{1}$ nor $\pi_{2}$ are available. What is known are industry-level price indices $P_{1}$ and $P_{2}$ in the two periods, where in the second period the price index $P_{2}$ is in fact some unknown weighted average of old and new product price indices $P_{12}$ and $P_{22}$. Expressing the latter in terms of the former, so that $P_{21}=\left(1+\varphi_{1}\right) P_{2}$ and $P_{22}=\left(1+\varphi_{2}\right) P_{2}$, we obtain that the growth rates of old and new prices $\pi_{1}$ and $\pi_{2}$ are respectively related to the industry price growth rate $\pi$ as follows:

$$
\pi_{1}=\pi+\varphi_{1}(1+\pi) \text { and } \pi_{2}=\pi+\varphi_{2}(1+\pi)
$$

where $\varphi_{1}$ and $\varphi_{2}$ are the percent differences, varying across firms, between the unobserved "true" prices of the old and new products and the observed industry price.. We have used as proxies for $\pi$ the two digit industry price growth rates available from the statistical agency, which probably do not fully adjust for all the quality changes between the periods.

Replacing $\pi_{1}$ and $\pi_{2}$ by $\pi$, our estimating equation (12) thus becomes approximately:

$$
l-\left(g_{1}-\pi\right) \cong \alpha_{0}+\frac{\beta}{1+\bar{\varphi}_{2}} \frac{g_{2}}{(1+\pi)}+\left[u-\varphi_{1}(1+\pi)\right]
$$

where $\left(1+\bar{\varphi}_{2}\right)$ is an average ratio of the quality-adjusted price of the new products to the share-weighted price of old and new products.

This equation expresses the growth in employment relative to the real output growth in old products as a function of the growth in real new products, where real output in old and new products are measured by deflating the corresponding nominal sales by overall industry level price indices. It shows two important differences with equation (12). First, the coefficient of the new product term is not $\beta$, the relative 
efficiency of producing new versus old products, but $\beta$ divided by $\left(1+\bar{\varphi}_{2}\right)$. If there is substantial (measured) quality improvement in the new product whose cost is passed on to consumers, leading to higher "effective" prices, $\bar{\varphi}_{2}$ will be greater than zero and the pass-through from its sales growth to labor growth will be moderated relative to the case of little quality change. On the other hand, if quality improvement leads to lower "effective" prices, $\bar{\varphi}_{2}$ will be less than zero, and new product sales will have an enhancing effect on labor growth.

This interpretation is similar to that given by Griliches and Mairesse (1984) for their "semi-reduced form" estimates of an extended production function with both physical and R\&D capital stocks: R\&D can either improve efficiency (declines in $\beta$ ) or quality (increases in $\bar{\varphi}_{2}$ ). Without good information on quality-adjusted prices we cannot separate the two effects.

The second difference in equation (14) is in the component $\varphi_{1}(1+\pi)$ in the disturbance, which is another likely source of endogeneity into the equation, beyond that due to the simultaneous choice by the firm of its output and labor input. This should, however, remain a minor problem, since old products make up a large share of sales on average, implying that $\varphi_{1}$ is small.

\section{The data}

The data we use come from the $7^{\text {th }}, 8^{\text {th }}$, and $9^{\text {th }}$ waves of the "Survey on Manufacturing Firms" conducted by Mediocredito Capitalia (MCC). These three surveys were carried out in 1998, 2001, and 2004 using questionnaires administered to a representative sample of Italian manufacturing firms. Each survey covered the three years immediately prior (1995-1997, 1998-2000, 2001-2003) and although the survey questionnaires were not identical in all three of the surveys, they were very similar. All firms with more than 500 employees were included, whereas smaller firms were selected using a sampling design stratified by geographical area, industry, and firm size. We merged the data from these three surveys, excluding firms with incomplete information or with extreme observations for the variables of interest. ${ }^{5}$

\footnotetext{
${ }^{5}$ We required sales per employee between 2000 and 10 million euros, growth rates of employment and sales of old and new products between -150 per cent and 150 per cent, and R\&D employment share
} 
Our final sample is an unbalanced panel of 12,948 observations on 9,462 firms, of which only 608 are present in all three waves. ${ }^{6}$ Details on the variable construction are given in the Appendix.

Equations (12) and (14) require measures of $g_{1}$ and $g_{2}$, the sales growth attributed to old and new products respectively. In fact, we have in the three surveys $g$, the growth of nominal sales during the three year periods of the surveys (i.e., 19951997, 1998-2000, 2001-2003), and $s$, the share of sales in the last year of the surveys (i.e., 1997, 2000, 2003) that are due to new products introduced during their three year periods or substantially improved during these periods. Given the definitions of $g_{1}$ and $g_{2}$ [see (9) and (10)], we directly derive their expression in terms of $g$ and $s .{ }^{7}$ We thus obtain:

$$
g_{1}=(1-s) g-s \quad \text { and } \quad g_{2}=s(1+g)
$$

Note that these two "growth rates" sum to $g$ directly, without share weighting, so that they can be interpreted as the contribution to growth from the two sources. Note that $g_{2}$ is either null (if $s=0$ ) or positive (if $s>0$ ), but cannot be negative, and is not a rate of growth stricto sensu (see footnote 4).

Table 1 shows simple statistics for the unbalanced sample, both separately for the three periods and pooled together, as well as for the pooled balanced panel. In the appendix, Table A1 gives also these statistics for various other subsets of the unbalanced sample: R\&D-doing firms only, innovating firms only, and firms in high and low technology sectors. ${ }^{8}$

less than 100 per cent. We also replaced $R \& D$ employment share with the $R \& D$ to sales ratio for the few observations where it was missing.

${ }^{6}$ In an earlier version of this paper we have used a balanced panel of 466 firms. The results found for this sample and those presented here for the much larger unbalanced panel are very similar.

${ }^{7}$ More precisely $g$, the rate of change of firm sales between period $t=1$ and $t=2$, and $s$, the share of new products in total firm sales of period $t=2$, being respectively

$$
g=\frac{Y_{22} P_{22}+Y_{12} P_{12}-Y_{11} P_{11}}{Y_{11} P_{11}} \quad \text { and } \quad s=\frac{Y_{22} P_{22}}{Y_{22} P_{22}+Y_{12} P_{12}}
$$

we see easily that the sales growth due to new products and the sales growth due to old products are the following:

$$
g_{2}=\frac{Y_{22} P_{22}}{Y_{11} P_{11}}=s(1+g) \quad \text { and } \quad g_{1}=g-g_{2}=(1-s) g-s .
$$

\footnotetext{
8 "Innovating" firms are those that do some process and/or product innovation, as defined in the survey
} 
From Table 1, one can see that overall the three surveys the median firm has 33 employees and sales of 154,000 euros per employee; and that about 40 per cent of firms perform R\&D while 60 per cent innovate, either in processes or products. Firms in the balanced panel are slightly larger, with median employment of 38, and the proportion of those doing $\mathrm{R} \& \mathrm{D}$ is higher (60\%), while the proportion of innovating firms is about the same, with more of them reporting product innovation and fewer reporting process innovation only. Sales growth slowed considerably in the last three year survey period (2001-2003), as compared to the first and middle periods (19982000 and 1995-1997): from $8.7 \%$ and $7.6 \%$ down to $0.5 \%$. Since the growth in employment fell between the first and middle survey periods but not between the middle and last periods, there is an acceleration of labor productivity between the first two periods and an even more striking deceleration between the last two: respectively from $2.5 \%$ up to $6.2 \%$, and from $6.2 \%$ down to $-1.6 \%$. Note that the share $s$ of new products in total sales (or share on innovative sales) is relatively small: about $5.5 \%$ in the first survey period and nearly $10 \%$ in the two other ones.

Table A1 in the appendix shows that R\&D-doing firms are in average slightly larger than innovating firms, themselves larger than the other firms. About 50 per cent of the innovating firms do $R \& D$, while about 80 percent of the $R \& D$-doing firms innovate.. R\&D intensity of the R\&D-doing firms among the innovating firms is higher than that of the R\&D-doing firms overall (2.35\% versus 1.8\%). Although substantially fewer firms do $R \& D$ in low-tech industries than in the high-tech industries (34\% versus 59\%), only slightly fewer innovate (56\% versus $67 \%$ ).

\section{Results}

\subsection{Main estimates and variants}

Our main estimates of equations (12) and (14) using instrumental variables to correct for possible simultaneity and measurement biases, and by ordinary least questionnaire. 
squares (OLS) for comparison, are given in Tables 3 and 4. However, before discussing these estimates, it is instructive to begin by presenting the OLS estimates of simple descriptive regressions of the three-year employment growth $l$ on the threeyear real sales growth $g$ and on three dummies for innovation in these periods: process innovation only, product innovation only, and both process and product innovation. These estimates are shown in Table 2, first for the three survey periods separately, and then pooled over these three periods, but with separate intercepts for each of them. Tests of slope and dummy coefficient equality over time are generally accepted. We have included industry dummies at the two digit level (i.e. at the same level as the industry price deflators $\pi$ ) in all the regressions. As we are interested in preserving the value of the intercept, we apply a linear constraint to the dummies so that the estimated sum of their coefficients is equal to zero (Suits 1957) and include an intercept, which therefore corresponds to the overall mean effect.

\section{[Table 2 about here]}

The coefficient of real sales growth in this simple regression is always significant and well below unity, implying that for non-innovating firms, employment growth is substantially dampened relative to the growth of real sales. However, the growth rate of employment for innovating firms is much higher. With the exception of process innovation in the first survey period, the coefficients of all three innovation dummies are positive and increasing over the three periods, although only the process-product dummy is always significantly different from zero.

For the pooled estimates, if sales growth increases by one per cent, noninnovators' employment increases by about 0.25 per cent. However, firms that introduce new processes but not new products have an average growth of employment that is 0.60 per cent higher than non-innovating firms whereas firms that introduce new products without new processes have an average growth of employment that is about one per cent higher. Those that innovate in both ways have a growth of employment about two per cent higher, which is about one third higher than the sum of the two separate effects, suggesting some form of complementarity. Clearly innovation is associated with increases in employment. However, all these OLS estimates are likely to be downward biased because of simultaneity between the output and labor growth rates variables and because of measurement errors, due in 
particular to the lack of output price indices at the firm level (see previous sub-section $3.3)$.

Table 3 presents both OLS and Instrumental Variable (IV) estimates of equation (14), in the same format as in Table 2, but where now the employment growth rate minus the growth rate of the deflated sales due to old products $\left(l-g_{l}+\pi\right)$ is the left hand side variable and the growth rate of deflated sales due to new products $\left(g_{2} /(1+\pi)\right)$ is a right hand side variable.. The instruments for sales growth due to new products are a dummy variable for positive $R \& D$ expenditures in the last year of the three year survey period, the same dummy lagged one year (in the middle year of the survey period), the R\&D employment intensity in the last year of the survey period, and a dummy variable for whether the firm assigned high or medium importance to developing a new product as the goal of its investment. The coefficient of the sales growth due to new products estimated by IV are not significantly different from one, implying that no significant differences exist between the efficiency levels of production of old and new products. Note that they are close to those estimated by OLS but much less precise as expected. The negative of the constant term gives an estimate of the average productivity growth for the old products: $4.0 \%$ from 1995 to 1997, 5.8\% from 1998 to 2000, and $-1.7 \%$ from 2001 to 2003. These values are close to what we see in Table 1 for the average productivity growth for all products, which is not surprising since the average share of old products in sales is more than 90 per cent.

\section{[Table 3 about here]}

In Table 4 we consider three specifications of equation (14) trying to take into account process innovation, (as proposed in equation (7) in sub-section 3.2). It should be kept in mind that we have only a binary indicator for process innovation in the survey, and thus we cannot quantify how important such innovation is nor can we know how much applies to the production of old products, new products, or both. In the upper panel of Table 4, we give the estimates for the simplest (and our preferred) specification, in which we include a dummy for process innovation only (i.e., only for

firms with no product innovation), thus not trying to disentangle the effects of process and product innovations in the case of new products. In this specification, a negative coefficient for "process innovation only" indicates an increase in the productivity of 
manufacturing the old products and a displacement of employment. The estimates are indeed negative (except for the middle survey period), but rather small and not statistically significant (except for the all years sample at a $10 \%$ confidence level), implying no impact, or a small one, on productivity, and little or no displacement effects.

\section{[Table 4 about here]}

In the middle panel of Table 4 we include in the specification an additional dummy for product and process innovation together, while in the lower panel we include another variable which interacts the sales growth variable due to new products with the process innovation dummy. In a sense we are trying to separate two extreme cases, assuming in the middle panel specification that process innovation of product innovators can be fully attributed to old products, and in the lower panel specification that it is fully attributed to new products. Of course, the truth probably lies somewhere in between these two extreme cases. The results are disappointing and do not add much compared to the first panel: the only variable that is significantly related to employment growth throughout the three survey periods is the growth of sales of new products, with a coefficient of unity.

Thus the main conclusion from Table 4 is that there is no difference in the efficiency with which old and new products are produced, although firms that introduce process innovations do experience a slight increase in labor productivity during the whole period that is not related to sales growth (either of old or new products). In these specifications, the constant term (the estimate of the average productivity growth of the old products) displays the same pattern as in Table 3, showing that non-innovators did lose employment on average between 1995 and 2003.

Tables A2a and A2b in the appendix show the OLS and IV estimates of our preferred specification with the dummy for process innovation only (the first panel) for high-tech and low-tech industries separately. We see that the productivity slowdown in the last survey period (2001-2003) as compared to the first period (19951997) occurred about equally in the high tech and low tech industries, but the productivity gain during the middle (1998-2000) period was much higher in the lowtech sector than in the high-tech sector. We also note that unlike what we observe for 
manufacturing as a whole, the high tech sector exhibits evidence either of greater efficiency in producing new products $(\beta<1)$ or quality increases that are passed on to consumers in the form of higher prices for new products $\left(\varphi_{2}>0\right)$, or both.

\subsection{A simple (but effective) employment growth decomposition}

Another way to summarize our results is to consider the following decomposition of employment growth into several components:

$$
l=\left\{\begin{array}{cc}
\sum_{j}\left(\hat{\alpha}_{0}+\hat{\alpha}_{0 j}\right) \text { Dind }_{j}+ & \text { due to specific productivity trend in old products; } \\
\hat{\alpha}_{1} d+ & \text { due to process innovation in old products; } \\
{\left[1-1\left(g_{2}>0\right)\right]\left(g_{1}-\hat{\pi}\right)+} & \text { due to output growth of old products; } \\
1\left(g_{2}>0\right)\left(g_{1}-\hat{\pi}+\hat{\beta} \frac{g_{2}}{1+\hat{\pi}}\right)+ & \text { due to product innovation (net of substitution); } \\
\hat{u} & \text { zero sum residual component. }
\end{array}\right.
$$

where the $\hat{\alpha} \mathrm{s}$ and $\hat{\beta}$ s are the estimated coefficients of our preferred specification (in the first panel of Table 4), $\operatorname{Dind}_{j}$ are the industry dummies, and $d$ the dummy variable for process innovation only.

For each firm, the first component accounts for the industry-specific productivity trend in the production of old products, and the second for the change in employment due to the net effect of process innovation in the production of old products. The third component is the change due to output growth of old products for the non product innovating firms. The fourth is the net contribution to employment growth of product innovation (for the product innovating firms), after adjustment for any substitution effect of old and new products. The last component is a zero-mean residual.

The results of this decomposition for all industries are reported in the upper panel of Table 5, for each survey period separately and then pooled. In the last two columns of this table, we also show the standard deviation of the estimated components across the pooled sample as well as the average standard error of the estimates, averaged across firms. ${ }^{9}$

\footnotetext{
${ }^{9}$ For example, the standard error of a component such as $f(\hat{\gamma}, x)$ is computed for each firm
} 
Focusing the discussion on the pooled analysis, we see that the average employment growth during the nine years 1993 to 2001 was of 3.2 per cent, of which about half $(1.7 \%)$ is accounted for by new product innovations, net of the induced substitution away from old products, and the remainder $(1.5 \%)$ by growth in the production of old products, net of any productivity gain. Process improvements in the firms producing old products reduce employment by a very small amount $(-0.2 \%)$ whereas changes attributable to the industry-specific productivity trends in these firms are larger $(-2.3 \%)$. These productivity enhancing effects are completely cancelled by the even larger increase (4.0\%) in employment associated with the output growth of these firms.

Looking at the standard errors, we see that the employment growth contributions of sales growth, either for old or new products, are significantly positive, whereas the average industry specific trend contribution is significantly negative. However perhaps the most noteworthy result is the substantial heterogeneity in observed employment growth (standard deviation of 15.6\%) and the fact that heterogeneity in unexplained employment growth (the residual) is increased (23.2\%) rather than reduced.

\subsection{Productivity growth decomposition}

In order to examine the impact of innovation on productivity growth more closely, an alternative decomposition of our estimating equation is useful, one which put (measured) real labor productivity on the left hand side, rather than employment:

by the so-called delta method and then averaged across firms, and its standard deviation is simply the standard deviation of $f(\hat{\gamma}, x)$ computed across the observations. 


$$
g-\hat{\pi}-l= \begin{cases}-\sum_{j}\left(\hat{\alpha}_{0}+\hat{\alpha}_{0 j}\right) \text { Dind }_{j} & \text { ind-specific productivity trend in old products } \\ -\hat{\alpha}_{1} d & \text { due to process innovation in old products } \\ +\left(1-\frac{\hat{\beta}}{1+\hat{\pi}}\right) g_{2} & \text { due to product innovation (net of substitution) } \\ -\hat{u} & \text { zero sum residual component }\end{cases}
$$

The first two terms in this decomposition are simply the negative of the contributions to employment growth. That is, for old products, increases in labor productivity translate one for one into decreases in employment. The third term is the contribution of product innovation (including any accompanying process innovation) to labor productivity growth.

The results of this decomposition are shown in the bottom panel of Table 5. For the three survey periods as a whole, average productivity growth was 2.5 per cent, and most of this growth was accounted for by improvements in the production of old products that were not related to innovation. Process innovation in producing old products and product innovation both have a very small positive impact, so the net impact of innovation on productivity growth in Italian firms during the 1994-2003 decade is effectively zero. The individual three year periods show variable patterns, with some effect of process innovation on productivity growth in the first period and of product innovation in the second. However, this positive impact of product innovation is almost entirely cancelled by a negative one in the third period.

The conclusion is that the slowdown in productivity of Italian manufacturing firms during the 2000-2003 period relative to the 1997-2000 period (a difference of about -7.8 per cent) is due mainly to overall trends in productivity that are not associated with innovation. The decrease in productivity growth that can be imputed to product innovation account for about 1.2 per cent only of this slowdown. Note, however, that if the new products had true quality-adjusted prices that were lower than the prices of old products, true productivity for firms that innovate in products would be correspondingly higher. There is no way to assess such an effect without detailed price data information that is not available (and actually does not exist), but it is likely to be fairly small, given the relatively modest share of innovative sales. 


\subsection{A rough comparison with France, Germany, Spain and the U.K.}

As mentioned earlier, an analysis similar to ours has been carried out by HJMP 2005 for manufacturing and service industries in France, Germany, Spain and the United Kingdom (U.K.) using data from the third Community Innovation Survey, which covers the period 1998-2000. Even though the sample design and the questionnaire are slightly different from ours, it is still worthwhile comparing their estimates with the results obtained for Italy. In the appendix, Table A3 presents the results of estimating a specification of the model that is exactly the same as the one they used:

$$
l-\left(g_{1}-\pi\right)=\alpha_{0}+\alpha_{1} d+\beta g_{2}+v
$$

The estimates are very similar to our preferred ones in the top panel of Table 4, although the intercept (the negative of the average productivity gain adjusted for industrial composition change) is slightly lower, which implies that the average productivity gain net of process innovation and growth in new product sales is higher when the new product sales are not adjusted for inflation.

In Table 6 we compare the estimates of HJMP 2005 for manufacturing industries in France, Germany, Spain and the U.K. for the period 1998-2000 with our corresponding estimates for Italy. The sample sizes are roughly comparable for France, Spain and Italy, and smaller for the U.K. and Germany. The instruments used are different, HJMP 2005 relying mainly on a dummy variable for the impact of innovation on increasing the range of products offered, as reported by the firm. The estimated coefficient of the sales growth due to new products is very similar and around one for all five countries. The estimated coefficient of the process innovation only dummy is negative and significant for Germany and the U.K., indicating an increase in productivity for the old products; for France and Italy it is not significantly different from zero, while for Spain it is positive, but barely significant. According to HJMP 2005, a large pass-through of productivity improvements to prices might possibly explain this positive effect for Spain.

The estimated intercept is significantly negative for all countries, with the highest values for Germany, Italy, and Spain. Not too surprisingly, manufacturing firms in the five countries which were producing old products only and that did not 
innovate in process (nor in products as well) experienced declines in employment during the 1998-2000 period, and conversely increases in labor productivity. For Italy only, product innovation appears to have been negative for employment, but note from Table 4 that this is true only for the 1998-2001 period; for the other periods product innovation is neutral or positive for growth even in Italy.

\section{[Table 6 about here]}

In Table 7 we compare the employment growth decomposition (based on the estimates of Table 6) across the five countries. In the 1998-2000 period, firm-level employment growth in Italy has been much slower than in the four other countries ( $2.5 \%$ in Italy versus percentage values ranging from $5.9 \%$ in Germany to $14.2 \%$ in Spain), and roughly in parallel with the estimated average contribution of new product innovation to employment growth $(2.4 \%$ in Italy versus percentage values ranging from $3.9 \%$ in the U.K. to $8.0 \%$ in Germany). The other components of the decomposition are also quite different. The sum of the average contributions of old products to employment growth is very high in Spain $(6.8 \%)$, also quite positive in France and the U.K. (about 2.8\%), approximately zero in Italy, and negative in Germany $(-2.1 \%)$. These effects all result from a substantial decline in employment growth due to productivity growth in the firms producing old products only, combined with a substantial increase due to output growth of old products in these same firms. We can nonetheless conclude from this comparison that firm employment growth in Italy during the three years 1998 to 2000 was much slower than in its four European counterparts largely because of the smaller contribution of product innovation.

[Table 7 about here]

\section{Conclusions}

In this paper we consider a simple model for employment growth, in which it is possible to disentangle the roles of displacement and compensation effects of innovation on employment growth at the firm level. Analyzing such mechanisms is of 
importance, because, as HJMP 2005 point out, the firm-level effects of innovation on employment are likely to determine the extent to which different agents within the firm behave with respect to innovation. Managers and workers have different incentives, and their behavior can foster or hamper innovation and technology adoption within the firm. Understanding better how these mechanisms work at the firm-level is central for the design of innovation policy and for predicting how labor market regulation can affect the rate of innovation.

Using data from the last three surveys on Italian manufacturing firms conducted by Mediocredito-Capitalia, covering the period 1995-2003, we estimate alternative specifications of our model of employment growth and we provide evidence that process innovation does not have significant displacement effects in Italian firms. We also find that the average productivity growth for existing products has been increasing until 2000 and declining thereinafter, signaling a widespread inability of Italian manufacturing firms to reallocate employment in order to fully exploit productivity gains stemming from process innovation. Comparing these results with the ones of HJMP 2005 for France, Germany, Spain and the U.K. indicates that the displacement effect for process innovation in all countries is quite small, and significant only for Germany and the U.K. Although partial, this evidence suggests that Italian firms may not be able to obtain productivity benefits from process innovation, possibly because of labor market rigidities.

We also find that about half of employment growth in Italy during the 19952003 period is contributed by product innovation and the other half by the sales growth of old products net of their productivity gains. Finally, although there are substantial productivity gains in the production of old products overall in Italy, these are more than cancelled by output growth in firms that did not introduce new products. As other researchers have found, the overall conclusion is that process innovation has little displacement effect in Italy and product innovation increases employment. However, the productivity decline during the period seems to come largely from non-innovating firms.

According to some recent evidence (Barba Navaretti et al, 2007), in the period subsequent to our analysis, these non-innovating firms have experienced a process of "creative destruction" due to increased competition from Asian countries. This selection mechanism has wiped away less efficient firms from the market, and reallocated their production both to new and incumbent firms. In this light, the 
productivity slowdown that we observe in the last period of our sample (2001-2003), may be attributed to the (slow) response of non-innovating firms to the exogenous increase in competition: these firms might have delayed exit in the hope to recover their competitiveness, causing a decrease in the aggregate productivity growth. 


\section{References}

Barba Navaretti, Giorgio, Matteo Bugamelli, Riccardo Faini, Fabiano Schivardi, and Alessandra Tucci (2007), "Le imprese e la specializzazione produttiva dell'Italia: dal macrodeclino alla microcrescita?", forthcoming in I vantaggi dell'Italia, Il Mulino, Richard Baldwin, Giorgio Barba Navaretti, and Tito Boeri Editors.

Blanchflower, David, and Simon Burgess (1998), "New Technology and Jobs: Comparative Evidence from a Two-Country Study." Economic Innovations and New Technology, n. 5, pp. 109-138.

Blechinger, Doris, Alfred Kleinknecht, Georg Licht, and Friedhelm Pfeiffer (1998) "The Impact of Innovation on Employment in Europe. An Analysis using the CIS Data." ZEW Documentation, 98-02.

Brouwer, Erik, Alfred Kleinknecht, and Jeroen-ON Reijnen (1993) "Employment Growth and Innovation at the Firm Level. An Empirical Study." Journal of Evolutionary Economics n.3, pp. 153-159.

Chennells, Lucy, and John V. Reenen (2002) "Technical Change and The Structure of Employment and Wages: a Survey on the Microeconometric Evidence." Productivity, Inequality and the Digital Economy, pp. 175-224. Greenan, N. and Y. L'Horty and J. Mairesse Editors; MIT Press.

Doms, Mark, Timothy Dunne, and Mark J. Roberts (1995) "The Role of Technology Use in the Survival and Growth of Manufacturing Plants." International Journal of Industrial Organization, n. 13, pp. 523-542.

Entorf, Horst, and Winfried Pohlmeier (1990) "Employment, Innovation and Export Activity: Evidence form Firm-Level Data." Microeconometrics: Surveys and Applications, pp. 349-415. Florens, J.P. and M. Ivaldi and J.J. Laffont and F. Laisney Editors.

Greenan, Nathalie, and Dominique Guellec (2000) "Technological Innovation and Employment Reallocation.” Labour n. 14, pp. 547-590.

Griliches, Zvi, and Jacques Mairesse (1984) "Productivity and $R \& D$ at the 
Firm Level." In R\&D, Patents and Productivity pp. 339-374. Griliches Z. Editor. Chicago University Press.

Hall, Bronwyn H., and Francis Kramarz (1998) "Effects of Technology and Innovation on Firm Performance, Employment, and Wages: Introduction." Economic Innovations and New Technology, n. 6, pp. 99-107.

Harrison, Rupert, Jordi Jaumandreu, Jacques Mairesse, and Bettina Peters (2005) "Does Innovation Stimulate Employment? A Firm-Level analysis Using Comparable Micro Data from four European Countries." Mimeo, Department of Economics, University Carlos III, Madrid.

International Monetary Fund (2006) "Country Study: Italy.” IMF Research Bulletin.

Klette, Tor Jacob, and Svein Erik Forre (1998) "Innovation and Job Creation in a Small Economy: Evidence from Norwegian Manufacturing Plants 1982-92." Economic Innovations and New Technology n. 5, pp. 247-272.

Lachenmaier, Stefan, and Horst Rottmann (2006) "Employment Effects of Innovation at the Firm Level." IFO Working Papers.

Lotti, Francesca, and Fabiano Schivardi (2005) "Cross Country Differences in Patent Propensity: a Firm-Level Investigation." Giornale degli Economisti e Annali di Economia n. 64 pp. 469-502.

Peters, Bettina (2004) "Employment Effects of Different Innovation Activities: Macroeconometric Evidence.” ZEW Discussion Papers, 04-73.

Piva, Mariacristina, and Marco Vivarelli (2005) "Innovation and Employment: Evidence from Italian Microdata." Journal of Economics n. 86, pp. 6583.

Say, Jean-Baptiste (1964), "A Treatise on Political Economy or the Production, Distribution and Consumption of Wealth", New York: Kelley. First edition, 1803.

Spiezia, Vincenzo, and Marco Vivarelli (2002) "Technical Change and Employment: a Critical Survey." In Productivity, Inequality and the Digital Economy pp. 101-131. Greenan N. and Y. L'Horty and J. Mairesse Editors. MIT Press. 
Suits, Daniel B. (1957) "Use of Dummy Variables in Regression Equations." Journal of the American Statistical Association n. 52, pp. 548-551.

Van Reenen, John (1997) "Employment and Technological Innovation: Evidence from U.K. Manufacturing Firms." Journal of Labor Economics n. 2, pp. $255-284$.

Vivarelli, Marco, and Mario Pianta eds (2000) "Employment Impact of Innovation: Evidence and Policy." Routledge, London.

Zimmermann, Klaus F. (1991) "The Employment Consequences of Technological Advance: Demand and Labour Costs in 16 German Industries." Empirical Economics n. 16, pp. 253-266. 
Table 1 - Descriptive statistics, sample firms, all industries

\begin{tabular}{|c|c|c|c|c|c|}
\hline & 1995-1997 & 1998-2000 & 2001-2003 & All years & $\begin{array}{c}\text { Balanced } \\
\text { Panel }\end{array}$ \\
\hline Number of observations (firms) & 4290 & 4618 & 4040 & $\begin{array}{l}12948 \\
(9462)\end{array}$ & $\begin{array}{l}1824 \\
(608)\end{array}$ \\
\hline$\%$ firms doing R\&D & 35.57 & 41.40 & 48.44 & 41.67 & 49.51 \\
\hline$\%$ firms doing innovation & 73.10 & 46.51 & 59.80 & 59.47 & 60.53 \\
\hline $\begin{array}{l}\text { R\&D exp. over sales } \\
\text { (in per cent) }\end{array}$ & 1.70 & 1.94 & 1.73 & 1.79 & 2.10 \\
\hline $\begin{array}{l}\text { R\&D exp. per employee } \\
\text { (in thousands of euros) }\end{array}$ & 2.70 & 3.22 & 3.16 & 3.05 & 3.54 \\
\hline $\begin{array}{l}\text { Share of innovative sales }(s) \\
\text { (in percent) }\end{array}$ & 5.39 & 9.99 & 9.62 & 8.33 & 11.72 \\
\hline $\begin{array}{l}\text { Sales/employee: mean/median } \\
\text { (in thousands of euros) }\end{array}$ & $185.7 / 139.3$ & $189.6 / 143.8$ & 247.1/188.0 & 206.3/154.1 & 193.8/153.5 \\
\hline Number of employees: mean/median & $116.30 / 34$ & $88.24 / 25$ & $142.43 / 49$ & $114.45 / 33$ & $136.4 / 38$ \\
\hline $\begin{array}{l}\text { Employment growth }(l) \\
\text { (in per cent) }\end{array}$ & 5.05 & 2.54 & 2.13 & 3.24 & 0.94 \\
\hline $\begin{array}{l}\text { Real sales growth }(g-\pi) \\
\text { (in per cent) }\end{array}$ & 7.59 & 8.74 & 0.49 & 5.78 & -2.44 \\
\hline$\%$ of firms with process innovation & 66.27 & 37.31 & 42.65 & 48.57 & 41.12 \\
\hline$\%$ of firms with product innovation & 30.44 & 27.33 & 45.77 & 34.11 & 49.67 \\
\hline $\begin{array}{l}\% \text { of firms with process innovation } \\
\text { only }\end{array}$ & 42.66 & 19.19 & 14.03 & 25.36 & 10.86 \\
\hline $\begin{array}{l}\% \text { of firms with process \& product } \\
\text { innovation }\end{array}$ & 23.19 & 15.61 & 24.48 & 20.89 & 25.82 \\
\hline $\begin{array}{l}\text { Sales growth attributed to old } \\
\text { products }\left(\mathrm{g}_{1}\right) \text {, in per cent }\end{array}$ & 5.90 & -1.10 & -4.57 & 0.14 & -3.69 \\
\hline $\begin{array}{l}\text { Sales growth attributed to new } \\
\text { products }\left(\mathrm{g}_{2}\right) \text {, in per cent }\end{array}$ & 5.80 & 10.98 & 8.86 & 8.60 & 10.96 \\
\hline Growth rate of prices $(\pi)$, in per cent & 4.10 & 1.14 & 3.81 & 2.95 & 3.09 \\
\hline
\end{tabular}

*Means are shown for the 4419 nonzero R\&D observations only. 
Table 2 - Employment growth regressed on real sales growth and innovation dummies Dependent variable: employment growth rate l (in \%)

\begin{tabular}{|c|c|c|c|c|c|c|c|c|c|c|c|c|}
\hline & \multicolumn{3}{|c|}{ 1995-1997 } & \multicolumn{3}{|c|}{ 1998-2000 } & \multicolumn{3}{|c|}{ 2001-2003 } & \multicolumn{3}{|c|}{ All years } \\
\hline & Coeff. & S.E. & & Coeff. & S.E. & & Coeff. & S.E. & & Coeff. & S.E. & \\
\hline Real sales growth $(g-\pi)$ & 0.25 & $(0.01)$ & $* * *$ & 0.17 & $(0.01)$ & $* * *$ & 0.26 & $(0.02)$ & $* * *$ & 0.23 & $(0.01)$ & $* * *$ \\
\hline Process inno only & -1.26 & $(0.91)$ & & 1.48 & $(0.63)$ & $* *$ & 1.22 & $(0.68)$ & $*$ & 0.60 & $(0.42)$ & \\
\hline Product inno only & 0.53 & $(0.59)$ & & 1.04 & $(0.42)$ & $* *$ & 0.85 & $(0.77)$ & & 0.96 & $(0.33)$ & $* * *$ \\
\hline Process \& product inno & 1.48 & $(0.76)$ & $* *$ & 1.92 & $(0.48)$ & $* * *$ & 2.57 & $(0.62)$ & $* * *$ & 2.04 & $(0.36)$ & $* * *$ \\
\hline Intercept & 2.02 & $(0.55)$ & $* * *$ & 0.32 & $(0.26)$ & & 1.53 & $(0.42)$ & $* * *$ & 2.37 & $(0.35)$ & $* * *$ \\
\hline Number of observations & & 4290 & & & 4618 & & & 4040 & & & 12948 & \\
\hline
\end{tabular}

OLS estimates. Robust standard errors are shown in parentheses; in the last column they are also clustered by firm. Significance levels: $* * * 1 \% * * 5 \% * 10 \%$

Two-digit industry dummies (and also period dummies in the last column) are included in all regressions. The intercept shown is the average of the industry dummy estimates. 
Table 3 - Employment and growth in innovative sales

Dependent variable: employment growth rate less real sales growth $l-g_{1}+\pi$ (in \%)

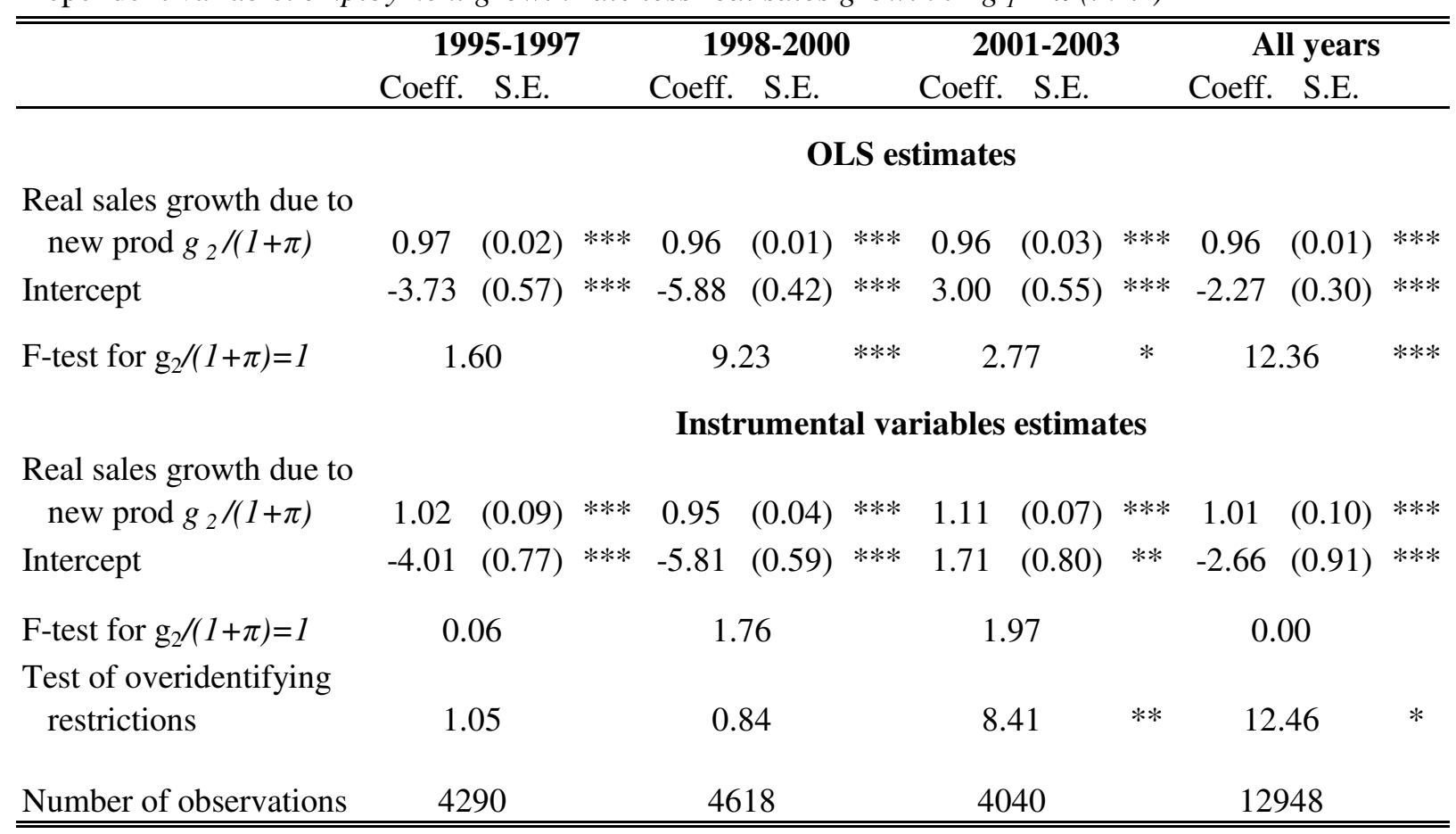

Robust standard errors are shown in parentheses; in the last column they are also clustered by firm.

Significance levels: $* * * 1 \% * * 5 \% * 10 \%$

Two-digit industry dummies (and also period dummies in the last column) are included in all regressions. The intercept shown is the average of the industry dummy estimates.

Instruments: R\&D intensity (R\&D employees/employees), a dummy for doing R\&D (current and lagged), and a dummy for whether investments are relevant to new product creation 
Table 4 - Employment and growth in innovative sales, including process innovation

Dependent variable: employment growth rate less real sales growth $l-g_{1}+\pi$ (in \%)

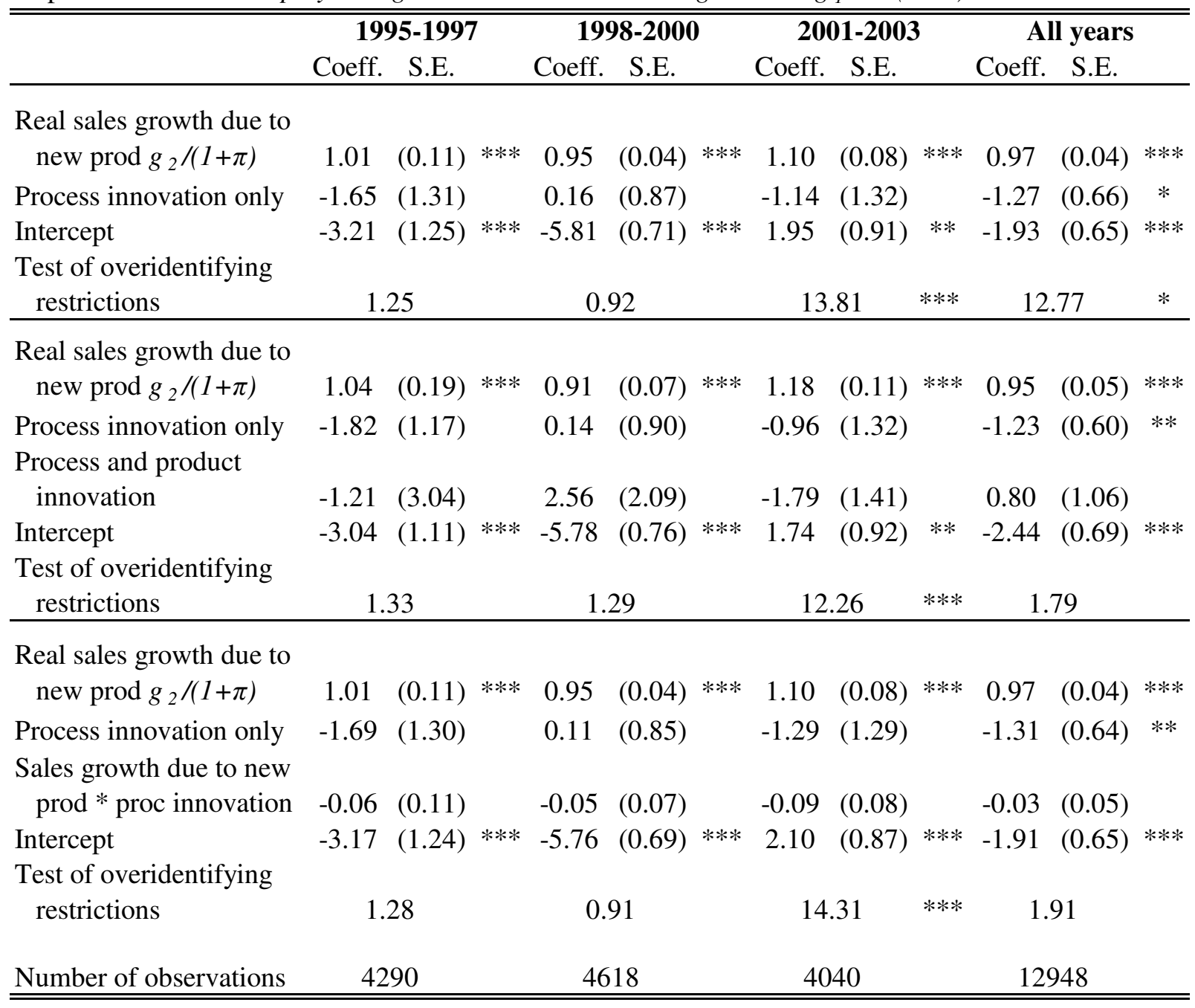

Robust standard errors are shown in parentheses; in the last column they are also clustered by firm.

Significance levels: $* * * 1 \% * * 5 \% * 10 \%$

Two-digit industry dummies (and also period dummies in the last column) are included in all regressions. The intercept shown is the average of the industry dummy estimates.

All estimates are instrumental variable estimates with same instruments as in the lower panel of Table 3: R\&D intensity

(R\&D employees/employees), a dummy for doing R\&D (current and lagged), and a dummy for whether investments are 
Table 5 - Growth decompositions: All industries, unbalanced panel.

\begin{tabular}{|c|c|c|c|c|c|c|}
\hline & \multicolumn{4}{|c|}{ Means } & \multicolumn{2}{|c|}{ Std. dev.* Std. err.** } \\
\hline & 1995-1997 & 1998-2000 & 2001-2003 & All years & All years & All years \\
\hline \multicolumn{7}{|c|}{ Employment growth } \\
\hline Employment growth, in \% & 5.05 & 2.54 & 2.13 & 3.24 & 15.58 & 0.00 \\
\hline Average industry specific trend & -1.70 & -5.51 & 1.32 & -2.27 & 4.62 & 1.04 \\
\hline Growth due to non-innovators & 6.04 & 5.67 & 0.05 & 4.04 & 20.40 & 0.00 \\
\hline $\begin{array}{l}\text { Growth due to process innovation } \\
\text { in old products }\end{array}$ & -0.70 & 0.03 & -0.17 & -0.20 & 0.34 & 0.17 \\
\hline Growth due to product innovation & 1.41 & 2.35 & 0.94 & 1.67 & 13.55 & 0.34 \\
\hline Residual component & 0.00 & 0.00 & 0.00 & 0.00 & 23.22 & 1.12 \\
\hline \multicolumn{7}{|c|}{ Productivity growth } \\
\hline Productivity growth, in $\%$ & 2.54 & 6.20 & -1.65 & 2.54 & 23.60 & 0.00 \\
\hline Average industry specific trend & 1.70 & 5.51 & -1.32 & 2.27 & 4.62 & 1.04 \\
\hline Growth due to process innovation & & & & & & \\
\hline in old products & 0.70 & -0.03 & 0.17 & 0.20 & 0.34 & 0.17 \\
\hline Growth due to product innovation & 0.14 & 0.72 & -0.50 & 0.07 & 1.07 & 0.34 \\
\hline Residual component & 0.00 & 0.00 & 0.00 & 0.00 & 23.22 & 1.12 \\
\hline
\end{tabular}

Based on estimates from the first panel of Table 4. Units are percents.

* The standard deviation of each component of the growth across the firm observations.

** The standard error computed for each observation based on the pooled coefficient estimates, and then averaged over the observations 
Table 6 -Employment growth and innovative sales: a comparison (1998-2000) Dependent variable: employment growth rate less real sales growth $l-g_{1}+\pi$ (in \%)

\begin{tabular}{lccccc}
\hline \hline & & \multicolumn{4}{c}{ CIS data } \\
& Italy & France & Germany & Spain & UK \\
\hline \multirow{2}{*}{ Sales growth due to new prod $g_{2}$} & 0.94 & 0.98 & 1.01 & 1.02 & 0.98 \\
& $(0.04)$ & $(0.06)$ & $(0.07)$ & $(0.04)$ & $(0.05)$ \\
Process innovation only & 0.18 & -1.31 & -6.19 & 2.46 & -3.85 \\
& $(0.87)$ & $(1.57)$ & $(2.92)$ & $(1.78)$ & $(1.87)$ \\
Intercept & -5.84 & -3.52 & -6.95 & -6.11 & -4.69 \\
& $(0.71)$ & $(0.78)$ & $(1.86)$ & $(0.90)$ & $(0.88)$ \\
Number of observations & 4618 & 4631 & 1319 & 4548 & 2493 \\
\hline \hline
\end{tabular}

The first column is taken from estimates in Table A3, while the others are from HJMP 2005, Table 6, column 1. Robust standard errors in parentheses. 
Table 7 - The employment growth decomposition: a comparison (1998-2000)

\begin{tabular}{|c|c|c|c|c|c|}
\hline & \multirow{2}{*}{$\begin{array}{c}\text { MCC data } \\
\text { Italy } \\
\end{array}$} & \multicolumn{4}{|c|}{ CIS data } \\
\hline & & France & Germany & Spain & UK \\
\hline Employment growth, in \% & 2.5 & 8.3 & 5.9 & 14.2 & 6.7 \\
\hline Average industry specific trend & -5.6 & -1.9 & -7.5 & -5.7 & -5.0 \\
\hline Growth due to non-innovators & 0.1 & -0.1 & -0.6 & 0.3 & -0.4 \\
\hline $\begin{array}{l}\text { Growth due to process innovation } \\
\text { in old products }\end{array}$ & 5.7 & 4.8 & 6.0 & 12.2 & 8.3 \\
\hline Growth due to product innovation & 2.4 & 5.5 & 8.0 & 7.4 & 3.9 \\
\hline Number of observations & 4618 & 4631 & 1319 & 4548 & 2493 \\
\hline
\end{tabular}

The first column is taken from the estimates in Table 5 for 1998-2000, while the others are from HJMP 2005. Units are per cents. 


\section{Appendix A}

\section{Variable Definition and Additional Tables}

Share of sales due to new products $(s)$ : share of turnover in the last year of the survey due to new or significantly improved products introduced in the last three years.

Process innovation: a dummy variable which takes value 1 if the firm reports to have introduced new or significantly improved production process in the three years of the survey.

Product innovation: a dummy variable which takes value 1 if the firm reports to have introduced new or significantly improved products in the three years of the survey.

$R \& D$ expenditure: expenditure in $\mathrm{R} \& \mathrm{D}$ as reported by the firm in each year of the survey (th. of euro).

$R \& D$ personnel: employment devoted to $\mathrm{R} \& \mathrm{D}$ activities, as reported by the firm in each year of the survey (heads).

Industry dummies: a set of dummy variables reflecting the 2-digits "Ateco91" industry classification.

High-tech industries: encompasses high and medium-high technology industries (chemicals; office accounting \& computer machinery; radio, tv \& telecommunication instruments; medical, precision \& optical instruments; electrical machinery and apparatus, n.e.c.; machinery \& equipment; railroad \& transport equipment, n.e.c.).

Low-tech industries: encompasses low and medium-low technology industries (rubber \& plastic products; coke, refined petroleum products; other non-metallic mineral products; basic metals and fabricated metal products; manufacturing n.e.c.; wood, pulp \& paper; food, beverages \& tobacco products; textile, textile products, leather \& footwear). 
Table A1 - Descriptive statistics, for different subsamples of firms, all years, unbalanced panel

\begin{tabular}{|c|c|c|c|c|}
\hline & R\&D firms & $\begin{array}{c}\text { Innovating } \\
\text { firms }\end{array}$ & $\begin{array}{l}\text { High-tech } \\
\text { industries }\end{array}$ & $\begin{array}{l}\text { Low-tech } \\
\text { industries } \\
\end{array}$ \\
\hline Number of observations & 5395 & 7700 & 4039 & 8909 \\
\hline$\%$ firms doing $\mathrm{R} \& \mathrm{D}$ & 100.00 & 48.72 & 58.50 & 34.03 \\
\hline$\%$ firms doing innovation & 79.22 & 100.00 & 66.77 & 56.16 \\
\hline $\begin{array}{l}\text { R\&D exp. over sales } \\
\text { (in per cent) }\end{array}$ & 1.79 & 2.35 & 2.40 & 1.29 \\
\hline $\begin{array}{l}\text { R\&D exp. per employee } \\
\text { (in thousands of euros) }\end{array}$ & 3.05 & 3.99 & 4.01 & 2.25 \\
\hline $\begin{array}{l}\text { Share of innovative sales }(s) \\
\text { (in percent) }\end{array}$ & 13.43 & 13.03 & 10.94 & 7.17 \\
\hline $\begin{array}{l}\text { Sales/employee: mean/median } \\
\text { (in thousands of euros) }\end{array}$ & $211.5 / 164.8$ & $195.2 / 154.9$ & $192.5 / 153.7$ & $212.5 / 154.5$ \\
\hline $\begin{array}{l}\text { Number of employees: } \\
\text { mean/median }\end{array}$ & $164.41 / 50$ & $135.24 / 40$ & $172.05 / 40$ & $88.33 / 31$ \\
\hline $\begin{array}{l}\text { Employment growth }(l) \\
\text { (in per cent) }\end{array}$ & 3.96 & 4.27 & 3.98 & 2.91 \\
\hline $\begin{array}{l}\text { Real sales growth }(g-\pi) \\
\text { (in per cent) }\end{array}$ & 6.29 & 6.78 & 6.04 & 5.67 \\
\hline $\begin{array}{l}\% \text { of firms with process } \\
\text { innovation }\end{array}$ & 62.39 & 81.68 & 52.51 & 46.78 \\
\hline $\begin{array}{l}\% \text { of firms with product } \\
\text { innovation }\end{array}$ & 55.24 & 57.36 & 42.86 & 30.15 \\
\hline $\begin{array}{l}\% \text { of firms with process } \\
\text { innovation only }\end{array}$ & 16.83 & 42.64 & 23.92 & 26.01 \\
\hline $\begin{array}{l}\% \text { of firms with process } \& \\
\text { product innovation }\end{array}$ & 38.41 & 39.04 & 28.60 & 20.78 \\
\hline $\begin{array}{l}\text { Sales growth attributed to old } \\
\text { products }\left(\mathrm{g}_{1}\right) \text {, in per cent }\end{array}$ & -4.35 & -3.26 & -1.24 & 0.76 \\
\hline $\begin{array}{l}\text { Sales growth attributed to new } \\
\text { products }\left(g_{2}\right) \text {, in per cent }\end{array}$ & 13.80 & 13.22 & 11.19 & 7.42 \\
\hline $\begin{array}{l}\text { Growth rate of prices }(\pi) \text {, in } \\
\text { per cent }\end{array}$ & 3.16 & 3.18 & 3.91 & 2.52 \\
\hline
\end{tabular}

*Means are shown for the nonzero R\&D observations only. 
Table A2a - Employment and growth in innovative sales, high tech industries

Dependent variable: employment growth rate less real sales growth $l-g_{1}+\pi$ (in \%)

\begin{tabular}{|c|c|c|c|c|c|c|c|c|c|c|c|c|}
\hline & \multicolumn{3}{|c|}{ 1995-1997 } & \multicolumn{3}{|c|}{ 1998-2000 } & \multicolumn{3}{|c|}{$2001-2003$} & \multicolumn{3}{|c|}{ All years } \\
\hline & Coeff. & S.E. & & Coeff. & S.E. & & Coeff. & S.E. & & Coeff. & S.E. & \\
\hline & \multicolumn{12}{|c|}{ OLS estimates } \\
\hline $\begin{array}{l}\text { Real sales growth due to } \\
\text { new prod } g_{2} /(1+\pi)\end{array}$ & 0.95 & $(0.04)$ & $* * *$ & 0.95 & $(0.02)$ & $* * *$ & 0.84 & $(0.05)$ & $* * *$ & 0.92 & $(0.02)$ & $* * *$ \\
\hline Process innovation only & -1.26 & $(1.56)$ & & -0.57 & $(1.55)$ & & -2.75 & $(2.54)$ & & -1.52 & $(1.03)$ & \\
\hline Intercept & -4.41 & $(1.48)$ & $* * *$ & -4.52 & $(0.88)$ & $* * *$ & 4.50 & $(1.26)$ & $* * *$ & -5.09 & $(0.79)$ & $* * *$ \\
\hline \multirow{2}{*}{ F-test for $g_{2} /(1+\pi)=1$} & \multicolumn{2}{|c|}{1.60} & & \multicolumn{2}{|c|}{6.07} & $* *$ & \multicolumn{2}{|c|}{11.87} & $* * *$ & \multicolumn{2}{|c|}{18.98} & \\
\hline & \multicolumn{12}{|c|}{ Instrumental variables estimates } \\
\hline $\begin{array}{l}\text { Real sales growth due to } \\
\text { new prod } g_{2} /(1+\pi)\end{array}$ & 0.88 & $(0.14)$ & $* * *$ & 0.86 & $(0.07)$ & $* * *$ & 1.09 & $(0.16)$ & $* * *$ & 0.94 & $(0.07)$ & $* * *$ \\
\hline Process innovation only & -2.18 & $(2.32)$ & & -2.18 & $(1.96)$ & & 0.27 & $(3.22)$ & & -1.27 & $(1.39)$ & \\
\hline Intercept & -3.51 & $(2.25)$ & & -2.89 & $(1.51)$ & & 1.32 & $(2.26)$ & & -2.44 & $(1.23)$ & $* *$ \\
\hline F-test for $g_{2} /(1+\pi)=1$ & \multicolumn{3}{|c|}{0.75} & \multicolumn{2}{|c|}{4.30} & $* *$ & \multicolumn{2}{|c|}{0.33} & & \multicolumn{2}{|c|}{0.88} & \\
\hline $\begin{array}{l}\text { Test of overidentifying } \\
\text { restrictions }\end{array}$ & \multicolumn{3}{|c|}{0.10} & \multicolumn{3}{|c|}{0.26} & \multicolumn{2}{|c|}{8.22} & $* *$ & \multicolumn{2}{|c|}{2.77} & \\
\hline Number of observations & \multicolumn{2}{|c|}{1401} & & \multicolumn{2}{|c|}{1394} & & \multicolumn{2}{|c|}{1244} & & \multicolumn{2}{|c|}{4039} & \\
\hline
\end{tabular}

Robust standard errors are shown; in the last column they are also clustered by firm.

Significance levels: $* * * 1 \% * * 5 \% * 10 \%$

Two-digit industry dummies (and also period dummies in the last column) are included in all regressions. The intercept shown is the average of the industry dummy estimates.

Instruments: $R \& D$ intensity (R\&D employees/employees), a dummy for doing R\&D (current and lagged), and a dummy for whether investments are relevant to new product creation 
Table A2b - Employment and growth in innovative sales, low tech industries

Dependent variable: employment growth rate less real sales growth $l-g_{1}+\pi($ in $\%)$

\begin{tabular}{|c|c|c|c|c|c|c|c|c|c|c|c|c|}
\hline & \multicolumn{3}{|c|}{ 1995-1997 } & \multicolumn{3}{|c|}{ 1998-2000 } & \multicolumn{3}{|c|}{ 2001-2003 } & \multicolumn{3}{|c|}{ All years } \\
\hline & Coeff. & S.E. & & Coeff. & S.E. & & Coeff. & S.E. & & Coeff. & S.E. & \\
\hline & \multicolumn{12}{|c|}{ OLS estimates } \\
\hline $\begin{array}{l}\text { Real sales growth due to } \\
\text { new prod } g_{2} /(1+\pi)\end{array}$ & 0.91 & $(0.03)$ & $* * *$ & 0.94 & $(0.02)$ & $* * *$ & 0.95 & $(0.03)$ & $* * *$ & 0.94 & $(0.01)$ & $* * *$ \\
\hline Process innovation only & -2.53 & $(0.96)$ & $* * *$ & 0.68 & $(0.74)$ & & -2.53 & $(1.26)$ & $* *$ & -1.37 & $(0.58)$ & $* *$ \\
\hline Intercept & -3.43 & $(0.97)$ & $* * *$ & -6.77 & $(0.70)$ & $* * *$ & -0.07 & $(0.77)$ & & -3.37 & $(0.64)$ & $* * *$ \\
\hline \multirow[t]{2}{*}{ F-test for $\mathrm{g}_{2} /(1+\pi)=1$} & \multicolumn{2}{|c|}{11.12} & $* * *$ & \multicolumn{2}{|c|}{7.67} & $* * *$ & \multicolumn{2}{|c|}{3.69} & $* *$ & \multicolumn{2}{|c|}{17.16} & $* * *$ \\
\hline & \multicolumn{12}{|c|}{ Instrumental variables estimates } \\
\hline $\begin{array}{l}\text { Real sales growth due to } \\
\text { new prod } g_{2} /(1+\pi)\end{array}$ & 1.02 & $(0.13)$ & $* * *$ & 0.99 & $(0.05)$ & $* * *$ & 1.06 & $(0.07)$ & $* * *$ & 1.02 & $(0.05)$ & $* * *$ \\
\hline Process innovation only & -1.59 & $(1.49)$ & & 1.17 & $(0.93)$ & & -1.57 & $(1.38)$ & & -0.57 & $(0.71)$ & \\
\hline Intercept & -4.37 & $(1.50)$ & $* * *$ & -7.33 & $(0.94)$ & $* * *$ & -1.00 & $(0.98)$ & & -0.60 & $(0.73)$ & \\
\hline F-test for $g_{2} /(1+\pi)=1$ & \multicolumn{3}{|c|}{0.02} & \multicolumn{3}{|c|}{0.05} & \multicolumn{3}{|c|}{0.57} & \multicolumn{2}{|c|}{0.28} & \\
\hline $\begin{array}{l}\text { Test of overidentifying } \\
\text { restrictions }\end{array}$ & \multicolumn{3}{|c|}{3.15} & \multicolumn{3}{|c|}{1.97} & \multicolumn{2}{|c|}{6.60} & $*$ & \multicolumn{2}{|c|}{8.38} & $* *$ \\
\hline Number of observations & \multicolumn{2}{|c|}{2889} & & \multicolumn{3}{|c|}{3224} & \multicolumn{2}{|c|}{2796} & & \multicolumn{2}{|c|}{8909} & \\
\hline
\end{tabular}

Robust standard errors are shown; in the last column they are also clustered by firm.

Significance levels: $* * * 1 \% * * 5 \% * 10 \%$

Two-digit industry dummies (and also period dummies in the last column) are included in all regressions. The intercept shown is the average of the industry dummy estimates.

Instruments: $R \& D$ intensity (R\&D employees/employees), a dummy for doing $R \& D$ (current and lagged), and a dummy for whether investments are relevant to new product creation 
Table A3 - Employment and growth in innovative sales, HJMP 2005 specification

Dependent variable: employment growth rate less real sales growth $l-g_{1}+\pi$ (in \%)

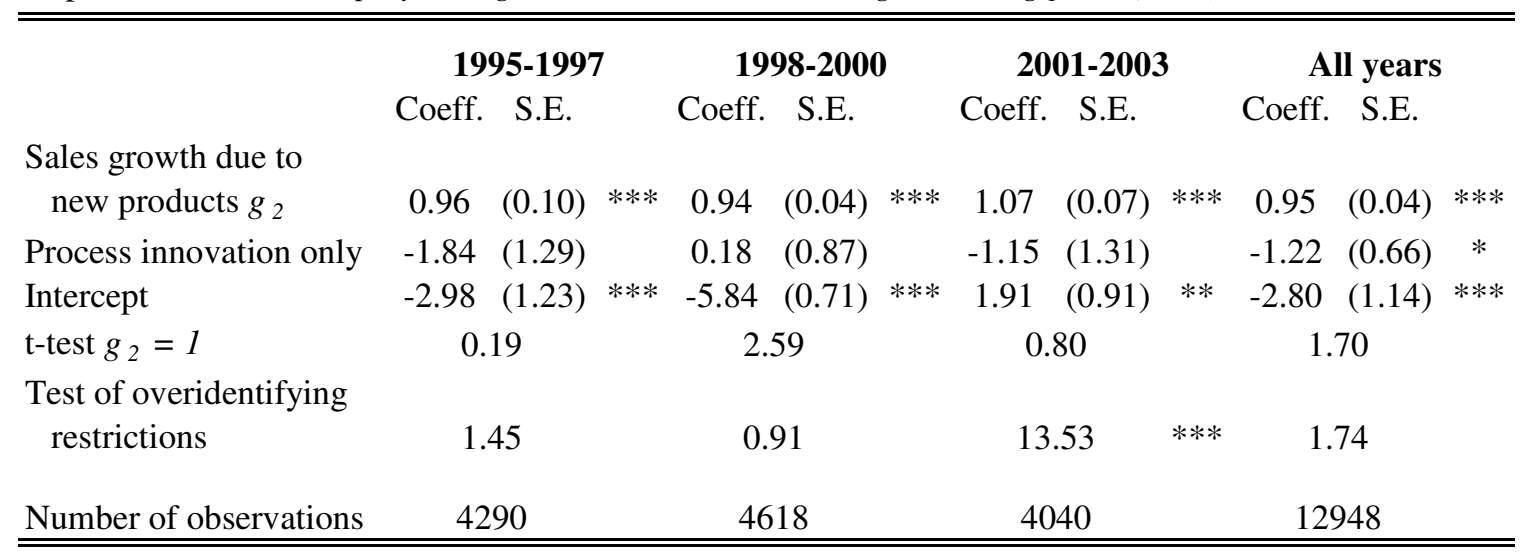

Robust standard errors are shown; in the last column they are also clustered by firm.

Significance levels: $* * * 1 \% * * 5 \% * 10 \%$

Two-digit industry dummies (and also period dummies in the last column) are included in all regressions. The intercept shown is the average of the industry dummy estimates.

Instruments: R\&D intensity (R\&D employees/employees), a dummy for doing R\&D (current and lagged), and a dummy for whether investments are relevant to new product creation 